\title{
SATELLITE AGROECOLOGICAL MONITORING WITHIN THE SYSTEM OF SUSTAINABLE ENVIRONMENTAL MANAGEMENT
}

\author{
O. H. Tarariko ${ }^{1}$, T. V. Ilienko ${ }^{1}$, T. L. Kuchma ${ }^{1}$, I. O. Novakovska ${ }^{2}$ \\ ${ }^{1}$ Institute of Agroecology and Environmental Economics, NAAS of Ukraine, \\ 12, Metrolohichna Str., Kyiv, Ukraine, 03143 \\ ${ }^{2}$ National Aviation University \\ 1, Kosmonavta Komarova prosp., Kyiv, Ukraine, 03058
}

E-mail:tarariko@ukr.net,tilienko@gmail.com,tanyakuchma@gmail.com,novmaill@ukr.net

Received January 12, 2019 / Received February 15, 2019 / Accepted March 22, 2019

Satellite data are a relevant part of information, required for sustainable environmental management, assessment of the impact of economic activity of ecosystems, determination of risks, related to global climate changes, desertification processes, loss of landscape and biotic diversity. Aim. To substantiate the reasonability and prove the efficiency of using satellite data in the agroecologic monitoring system regarding the impact of climate changes on vegetation, processes of soil erosion degradation, and assessment of landscape diversity. Methods. The study was conducted in the territory of Ukraine. It involved the application of SWOT and Gap-analysis methodology, materials of NOAA satellite observations, Sentinel, different spatial resolution, methodological and regulatory provision of the Institute of Agroecology and Environmental Economics of the National Academy of Agrarian Sciences regarding satellite monitoring of the structure of agrolandscapes, norms of establishing a network of testing agrarian grounds, list of vegetation state indicators, in particular, "Remote sensing of the Earth from space. Land data about controlling the condition of plantings and performance of agricultural crops. General requirements: DSTU 7307:2013", "Remote sensing of the Earth from space. Ground inspection of plantings. Classifier of objects and functions: SUC 01.1-37-907:2011", "Methodological recommendations on establishing the network of testing agrarian grounds in the system of monitoring of plantings using the materials of cosmic information". The investigation on the impact of climate changes on vegetation state was conducted on the territory of three natural-climatic zones which were geographically represented by Chernihiv, Poltava and Zaporizhzhia regions respectively. The determination of the threat of erosion degradation of arable lands and landscape diversity was performed on the territory of two administrative districts with high level of ploughness of agrolandscapes, intense agrarian production and manifestation of erosion degradation of lands. Results. Inadequacy of the traditional system of agroecological monitoring was determined. It was proven that it was reasonable to have comprehensive application of satellite data regarding climate warming within the natural climatic zones and its impact on vegetation according to the normalized difference vegetation index (NDVI), erosion degradation of soils and landscape diversity. According to satellite data of the National Oceanic and Atmospheric Administration (NOAA), the correlation analysis was performed on the connection between the dynamics of the sum of effective temperatures and the sum of NDVI values for the vegetation period. There was positive impact of climate warming on vegetation state according to NDVI index in the zone of Polissia and ForestSteppe. The correlation coefficients were $\mathrm{R}=0.64$ and $\mathrm{R}=0.77$ respectively. In the Steppe zone the correlation coefficient dropped down to $\mathrm{R}=0.35$ which demonstrated the elevated risk of droughts. Conclusions. Satellite data of Sentinel-1 were used to determine critical zones of erosion degradation of arable lands, requiring preservation and their inclusion to the natural fields, which had a positive impact on the optimization of agrolandscape diversity.

Keywords: satellite agroecological monitoring, testing agrarian grounds, landscape diversity, climate warming, drought, erosion degradation of soil, satellite data, sustainable environmental management, vegetation and landscape indices.

DOI:

\section{INTRODUCTION}

The implementation of the Rio Conventions on nature protection - the Convention on Climate Change

(C) O. H. TARARIKO, T. V. ILIENKO, T. L. KUCHMA, I. O. NOVAKOVSKA, 2019
(UNFCCC), the Convention to Combat Desertification (UNCCD), and the Convention on Biological Diversity (CBD) in agriculture requires joint solutions. First and foremost, it is related to improving the system of agroecological monitoring which provides for timely obtaining of information about cli- 
mate changes, manifestation of various degradation processes in agrolandscapes, their impact on environment and performance of agroecosystems.

\section{MATERIALS AND METHODS}

SWOT and Gap-analysis of agricultural policy were applied to implement the Rio Conventions within the framework of UNDP/GEF (United Nations Development Programme / Global Environmental Facility) "Integration of the Rio Conventions into the national policy of Ukraine" [1], the investigation involved the use of spatial imagery of different spatial resolution, methodological and regulatory provision of the Institute of Agroecology and Environmental Economics of the National Academy of Agrarian Sciences (IAEE NAAS) on establishing the network of testing agrarian grounds (TAG), the set of indices for vegetation, erosion degradation of soils and landscape diversity [2-4]. The investigation of the impact of climate changes on vegetation was conducted on the territory of natural-climatic zones of Polissia, Forest-Steppe and Steppe which were geographically represented by Chernihiv, Poltava and Zaporizhzhia regions respectively. The determination of erosion degradation of arable lands was conducted on the territory of Myroniv district of Kyiv region and Kaniv district of Cherkasy region. The territory of agricultural lands of these regions is characterized by high ploughness of agrolandscapes (up to $90 \%$ ), intense agrarian production and risks of water erosion, which is especially notable for $\mathrm{Ka}$ niv district.

The monitoring of climate warming impact on the vegetation state involved the use of NOAA satellite imagery, in particular, Smoothed Brightness Temperature (SMT) data of Advanced Very High Resolution Radiometer (AVHRR) and NDVI data for 1982-2018 [5]. Daily data of NOAA were averaged for weeks and used to determine the sum of effective temperatures and NDVI sum for a year and for a vegetative period (April-October).

The monitoring of erosion processes involved applying Sentinel-2 satellite data, isolating crop mask, and creating slope angle map based on depression contours in the 1:50,000 scale using QGIS software (https:// www.qgis.org/).

The monitoring of agrolandscape structure and preservation of biological diversity was performed by analyzing the landscape diversity indices in the system of experimental network of TAG on the territory of Myroniv and Kaniv districts, estimated using Fragstats software [6].

\section{RESULTS AND DISCUSSION}

It is common for global and domestic practice to assess and forecast climate changes using climate models, materials of traditional observations on meteorological stations as well as satellite data, which provide for spatial urgent evaluation of temperature regime, its impact on vegetation state and performance of agroecosystems $[7,8,10,11]$. In this respect, the data of the series of NOAA satellites in free access since 1982, are especially valuable. The analysis of the period from 1982 till 2018 involved the SMT data of AVHRR radiometer [5]. The flow charts of the sum of effective temperatures were built for Chernihiv, Poltava, and Zaporizhzhia regions (Fig. 1), which represent the zones of Polissia, Forest-Steppe, and Steppe respectively, along with algebraic trends for a year and for a vegetative period (April-October) (Fig. 2).

A consistent increase in the sum of effective temperatures (ST) by over 10 degrees in Chernihiv region during $1982-2017$ by $100{ }^{\circ} \mathrm{C}$, and in Poltava and Zaporizhzhia regions - by $150{ }^{\circ} \mathrm{C}$. On average for 35 years in Polissia (Chernihiv region), the sum of effective temperatures increased by $2.8^{\circ} \mathrm{C}$, and in the Forest-Steppe (Poltava region) and Steppe (Zaporizhzhia region) $-4.3{ }^{\circ} \mathrm{C}$.

The evaluation of the impact of climate changes on vegetation in the abovementioned pilot regions was conducted via correlation analysis of the interrelations between the temperature dynamics and NDVI, characterizing the vegetation state, as per the satellite data of AVHRR NOAA [12]. The distribution diagrams (Fig. 3) of the values of the sum of effective temperatures and cumulative NDVI (SNDVI) values for the vegetation period demonstrate high positive correlation between these two indices in Chernihiv region $(\mathrm{R}=0.77)$ and moderate positive correlation in Poltava region $(\mathrm{R}=0.64)$. At the same time, it was much lower in $\mathrm{Za}$ porizhzhia region, not exceeding $\mathrm{R}=0.35$, which may be explained by higher temperatures during development and moisture deficiency that led to the reduction in the rate of vegetative biomass accumulation which was in close correlation with NDVI index.

Thus, the increase in temperature has a positive impact on NDVI index, i.e. on the vegetation state, in Polissia (Chernihiv region) and Forest-Steppe (Poltava region). This relation is much weaker for Steppe (Za- 


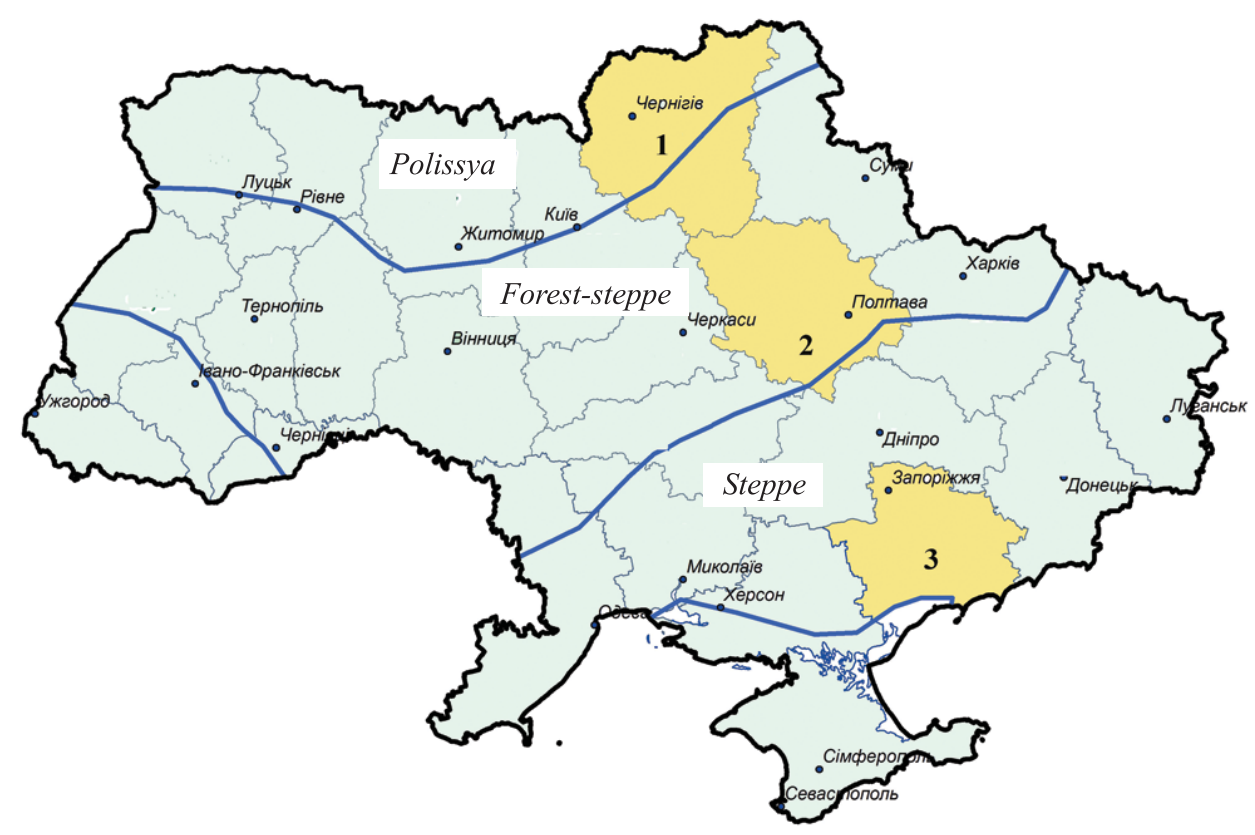

Fig. 1. Investigated regions: 1 - Chernihiv region, 2 - Poltava region, 3 - Zaporizhzhia region

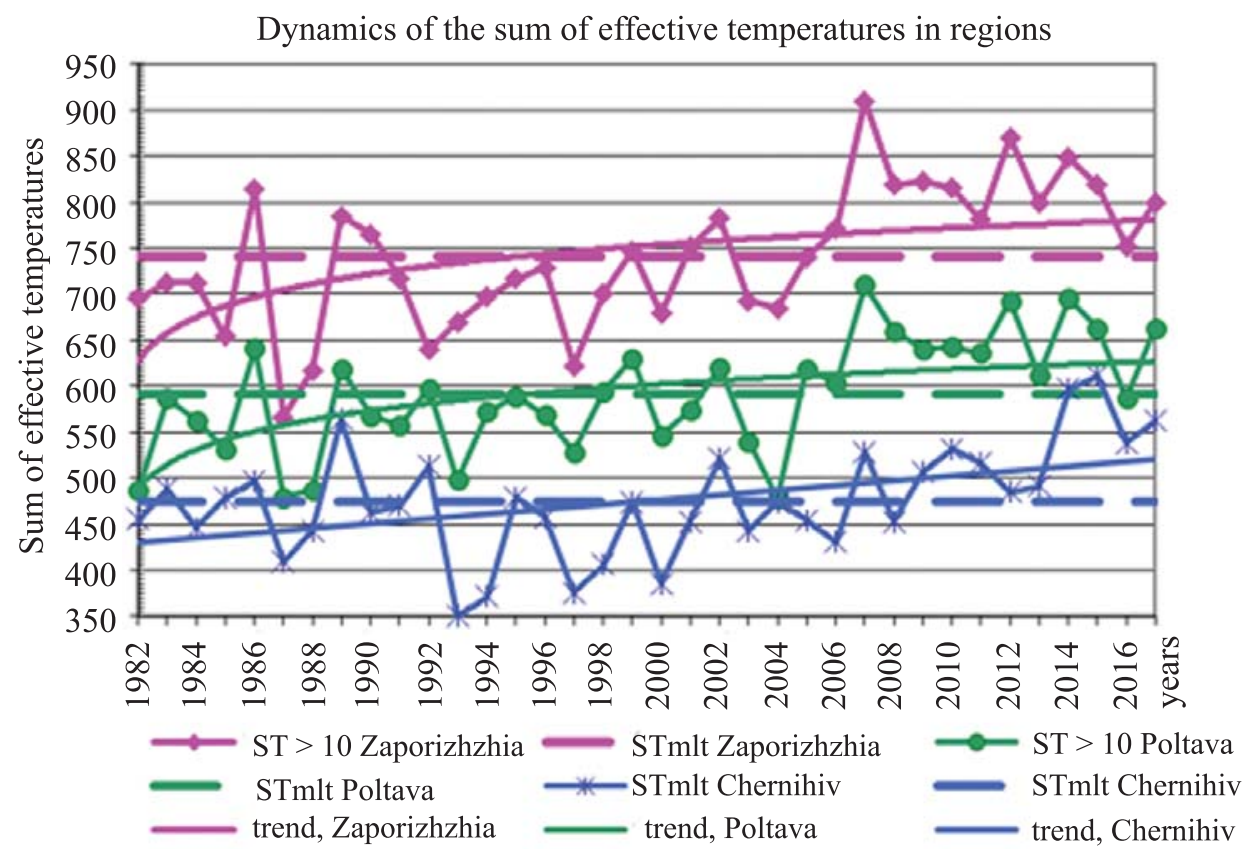

Fig. 2. The dynamics of the sum of effective temperatures on the territory of Chernihiv, Poltava, and Zaporizhzhia regions for 1982-2017, their trends, and average perennial values

porizhzhia region) which indicates the increased risk of drought and the relevance of applying agrotechnologies that ensure moisture accumulation in soil in autumn-winter.

The forecast of the Intergovernmental Panel on Climate Change demonstrated that climate change towards warming will lead both to droughts in continental areas of middle latitudes and to the increased frequency of daily extreme heavy showers regarding their total amount on the larger part of the globe [13]. On the one hand, it will increase the risks of moisture loss due to land drainage and evaporation considerably, and on the other hand, it will increase the threat of erosion in agrolandscapes which will lead to their degradation, decrease in soil fertility and reduction in agroecosystem performance. Thus, the relevance of the system of 
anti-erosion events in the area of about 13.0-15.0 million ha will be much higher [14].

It should be noted that market-type industrial structures were created instead of large agricultural enterprises during the years of the land reform. About 30 million ha of agricultural fields were divided into land plots (shares) and transferred for private ownership by 7 million citizens [14]. These actions resulted in the loss of a considerable number of anti-erosion boundaries and change in territorial organization of agricultural fields, which also had a negative impact on anti-erosion stability of agrolandscapes.

In these conditions there is a higher relevance of improving the traditional system of agroecological monitoring based on satellite data to ensure urgent evaluation of ecologic risks including the ones, related to moisture provision and erosion processes. Figure 4 presents a logical scheme of applying satellite information and geoinformation systems to analyze the degree of erosion degradation of the catch basin of a small river. The analysis results may serve as a basis for corrections in the structure of acreage within the catch basin, its adjustment to the terrain to form a balanced structure of agrolandscapes within catch basins of small rivers.

It is relevant to use satellite data to determine the compliance of locating the fields of corn, sunflower and other hoed crops in agrolandscapes with the provisions of soil protecting contour-meliorative spatial organization of agricultural fields. The differentiated use of arable lands via their division into three ecologictechnological groups (ETG) is an important element of this organization. ETG I covers lands with full profile and slightly eroded soils on plateau and slopes up to $3^{\circ}$; ETG II - lands, located on slopes of $3-5^{\circ}$ with slightly, moderately, and severely eroded soils; ETG III - lands on slopes over $5^{\circ}$, and $3-5^{\circ}$ with moderately and severely eroded soils [15]. The increase in anti-erosion stability of agrolandscapes also requires the removal of erosion-caused degraded arable lands with moderately and severely eroded soils for preservation and transfer to natural fields with further meadow formation or reforestation. Figure 5 presents the results of improving the land use structure of Kaniv and Myroniv administrative districts with the determination of arable lands, located on erosion-endangered slopes with the angle over $3^{\circ}$, and their removal for preservation and inclusion to natural fields.

In the agrolandscapes with complicated terrain, exceedingly high ploughness of agricultural fields up to
Chernihiv region, dependence of SNDVI on the sum of effective temperatures

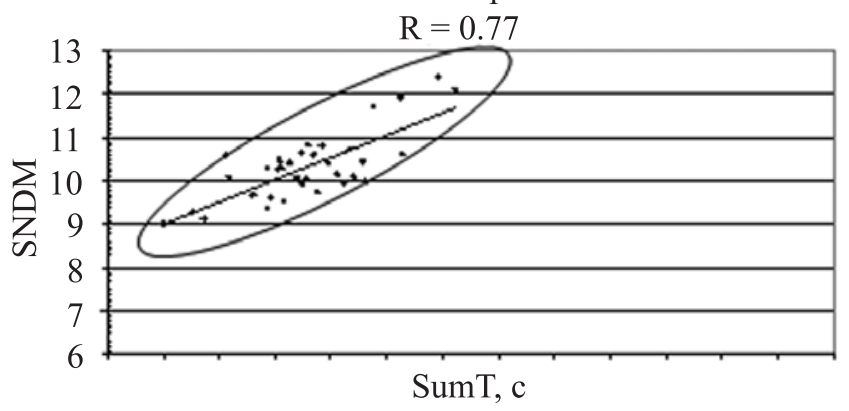

Poltava region, dependence of SNDVI on the sum of effective temperatures

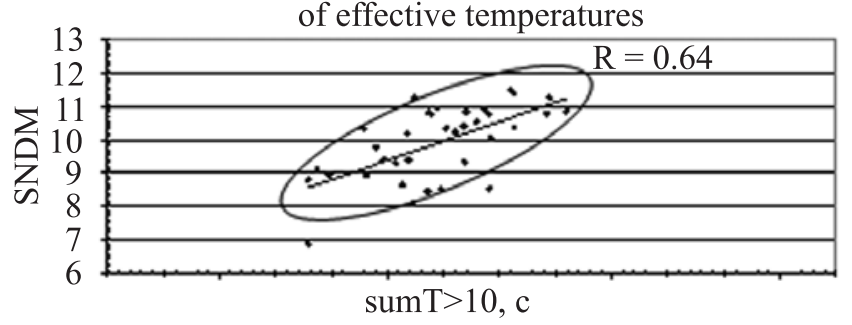

Zaporizhzhia region, dependence of SNDVI on the sum of effective temperatures

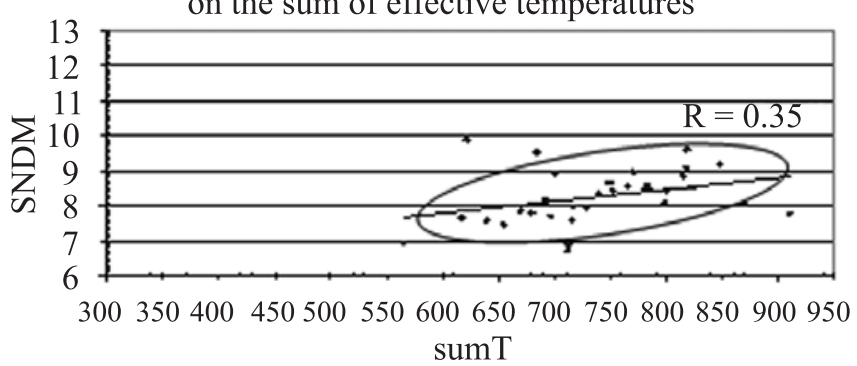

Fig. 3. The dependence of cumulative NDVI for the vegetation period on the sum of effective temperatures on the territory of Chernihiv, Poltava and Zaporizhzhia regions

$80-90 \%$, increase in the area of such erosion-related dangerous crops as corn and sunflower up to 50-60\% in the structure of fields, and with anticipated increase in the amount of precipitation in the form of heavy showers $[8,13]$, there are conditions for intensification of erosion processes and formation of gullies. It increases the risk of losing moisture due to land drainage, decrease in the level of groundwater, silting of small rivers with erosion products, which in general leads to desertification of agrolandscapes and, as a result, increased risk of reducing the performance of agroecosystems.

There is positive experience of fighting gully erosion on the territory of large ravine-gully systems: Norynsk (Zhytomyr region), Rzhyshchev-Kaniv (Cherkasy region) and many others. As project development and similar events were suspended on these territories, there is an increasing threat of intensified erosion processes, 


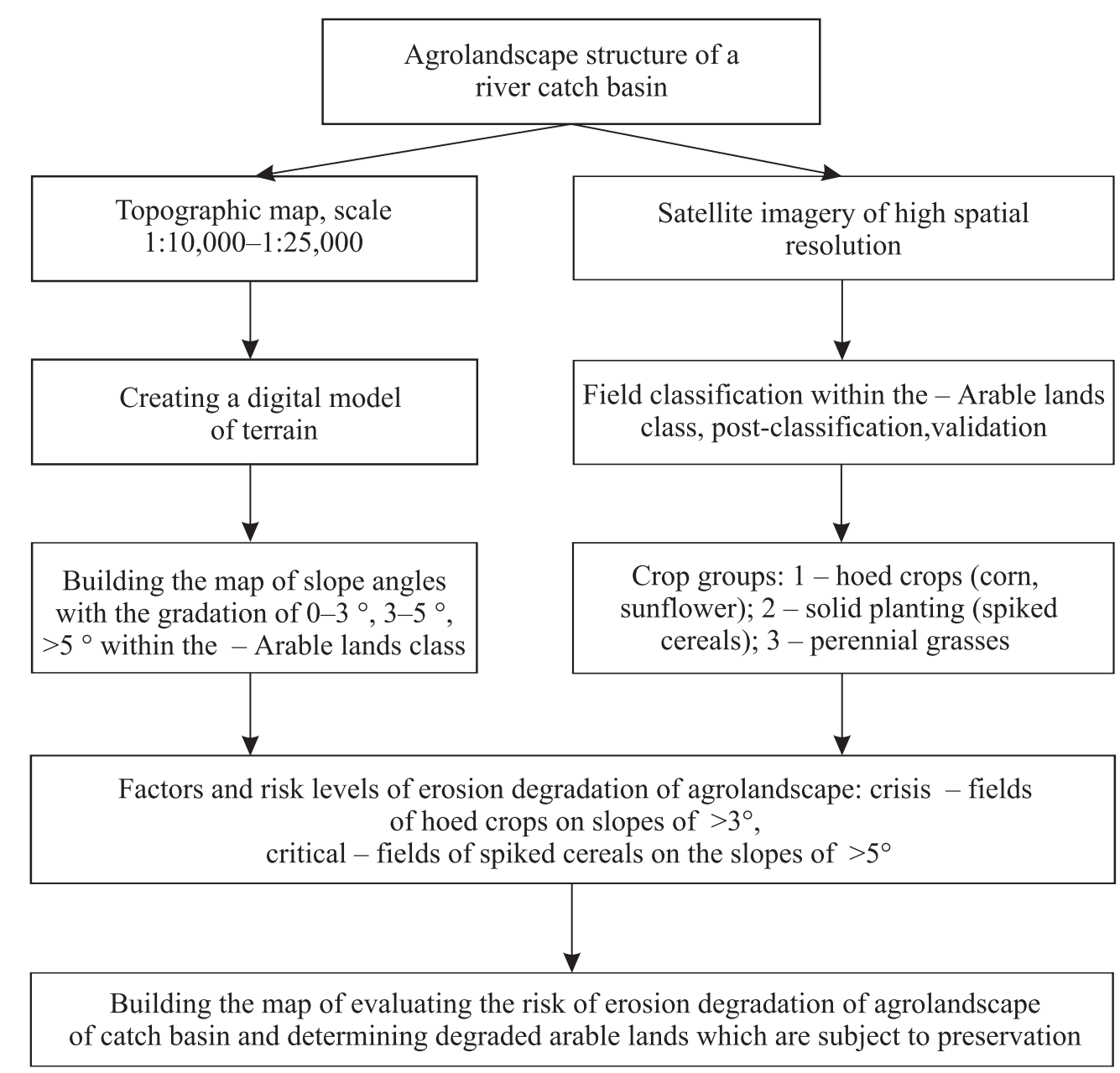

Fig. 4. Logical scheme of analyzing erosion degradation of the catch basin of a small river agrolandscape using remote sensing of the Earth/geoinformation systems

i.e. formation of gullys. For instance, the territory, covered by Kaniv forest drainage and irrigation station (Cherkasy region), has about 3.5 thousand registered gully heads. However, there is ongoing intensification of gully formation and a considerable number of antigully hydrotechnical buildings require reconstruction and repair.

Indicators of gully degradation of agrolandscapes are the ratio of gully area to the total area of agrolandscape $(\mathrm{km} / \mathrm{sq} . \mathrm{km})$; their length $(\mathrm{km} / \mathrm{sq} . \mathrm{km})$ and the density of territory breakdown (unit/sq.km) [15]. These three indicators are rather efficiently determined within the system of satellite monitoring which allows controlling the distribution of gully erosion, planning and designing relevant events.

Many landscape indices were developed in the system of satellite monitoring which characterize fragmentation, uniformity, division, complexity, heterogeneity or, vice versa, homogeneity $[6,16]$. The map schemes of territory zoning according to Shannon diversity index were used to compare the structure of two testing agrarian grounds: M14 with the dominating class of agricultural lands and $\mathrm{K} 7$ with prevalence of many fragments of different classes (Fig. 6).

The zoning of Kaniv district demonstrated that a large part of its territory is optimal by Shannon landscape diversity index which is confirmed by evenly distributed forests and meadows among arable lands and rather a low level of ploughness $(11.5 \%)$ of K7 testing agrarian grounds, located in the district. On the contrary, the structure of Myronivka district, especially its southern-eastern part, represented by M14 testing agrarian grounds, is characterized by homogeneity of agricultural lands and high ploughness $91.6 \%$, which allows characterizing it at a critical level in terms of landscape diversity.

It was established that agricultural fields in Myronivka district are located on slopes with the angle over $3^{\circ}$ 


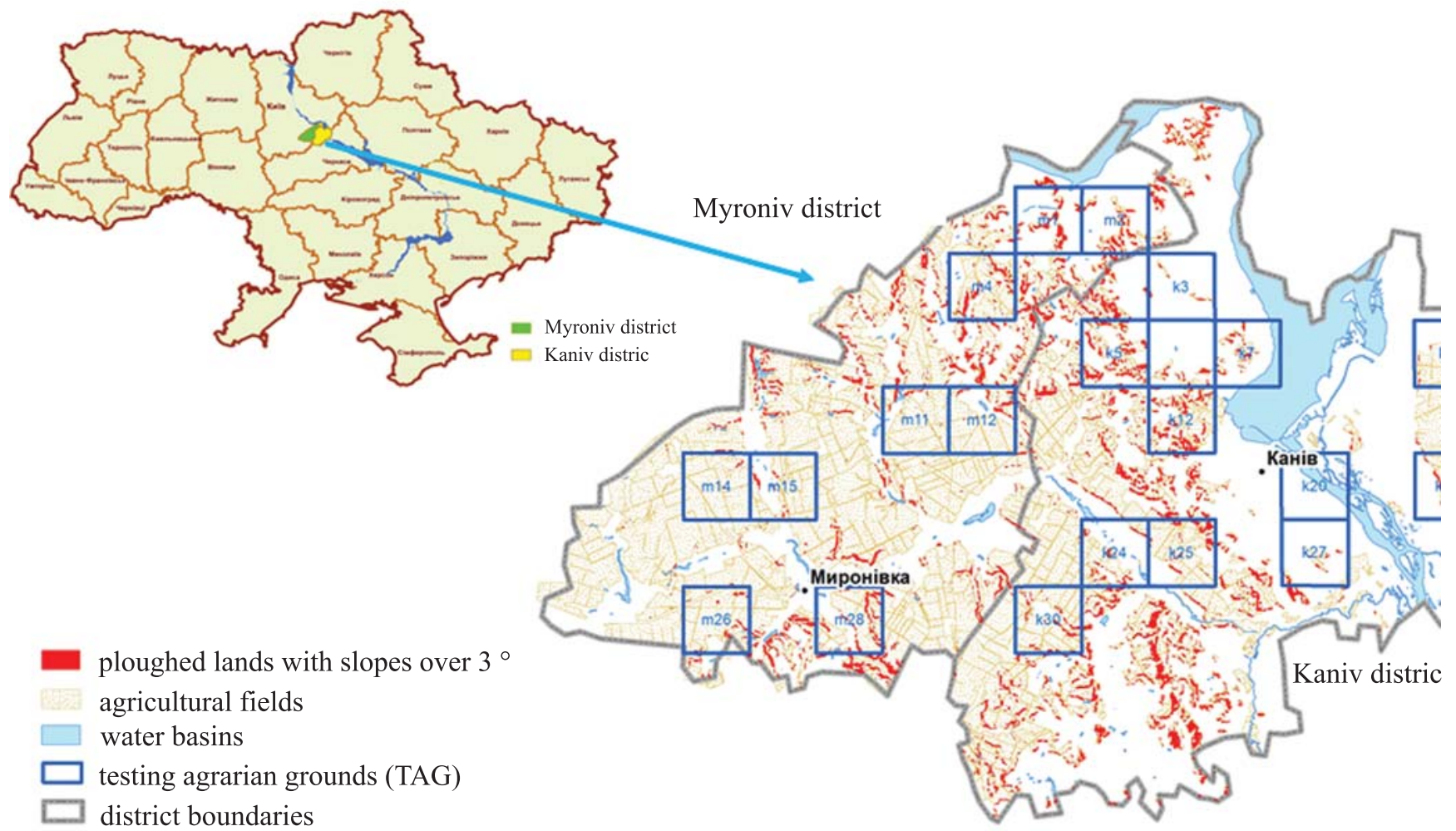

Fig. 5. Spatial structure of agricultural lands, arable lands on slopes over $3^{\circ}$ and the location of TAG on the territory of Myroniv (Kyiv region) and Kaniv districts (Cherkasy region), $\mathrm{m}_{\mathrm{i}}$ and $\mathrm{k}_{\mathrm{i}}$ - testing grounds of these districts, respectively

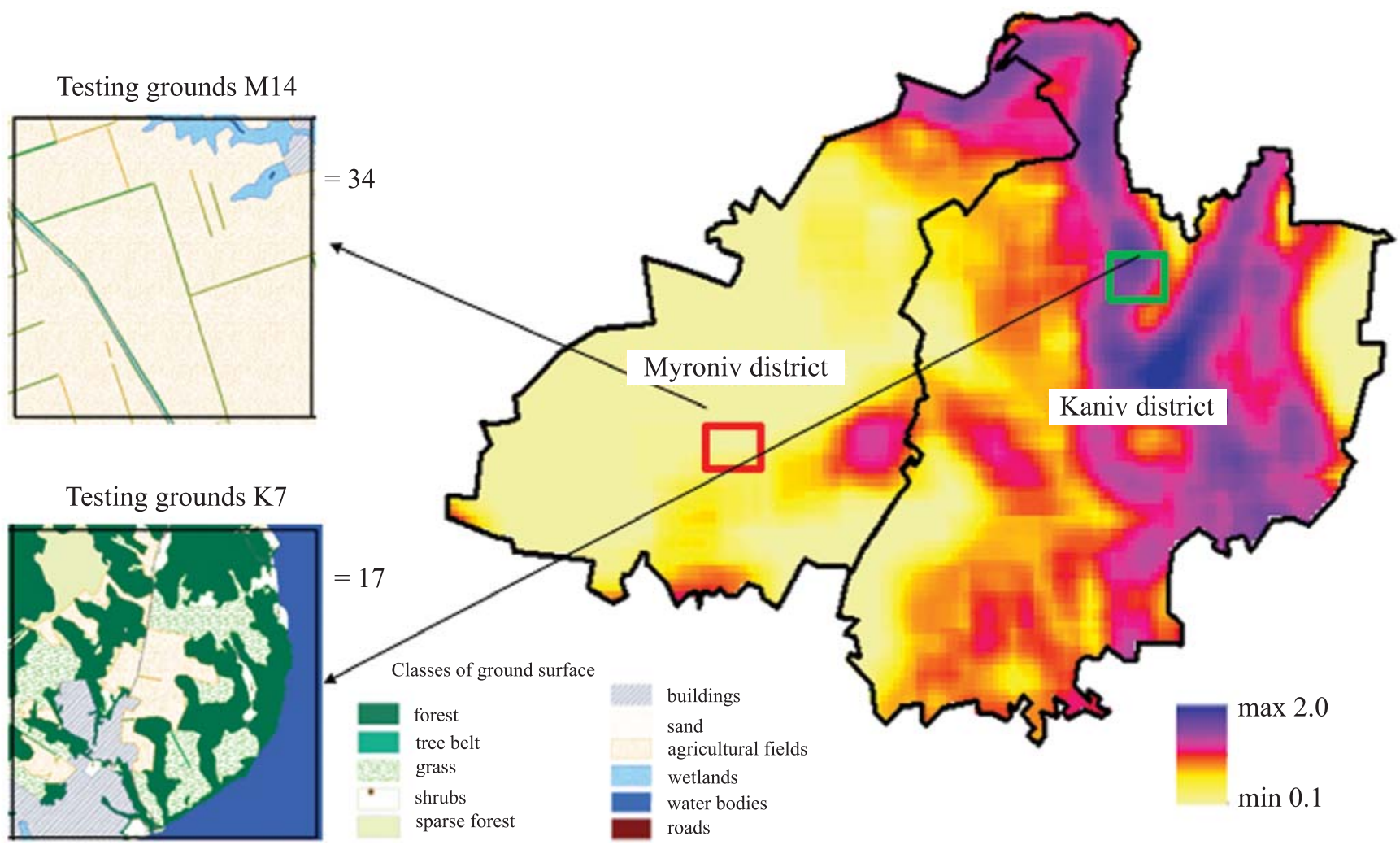

Fig. 6. Zoning the territory of Myroniv and Kaniv districts according to Shannon landscape diversity index 
on the area of 11.4 sq. $\mathrm{km}$ which is $1.9 \%$ from the total area. In Kaniv district these fields cover 14.8 sq.km. or $4.2 \%$ from the total area of land use (Fig. 5). If these fields are removed for preservation and creation of buffer zones with grass or forest vegetation, the value of Shannon landscape diversity index will increase by $2.9 \%$ for Kaniv district and by $2.6 \%$ for Myroniv district. The Table presents a change in landscape diversity values for each testing agrarian grounds, located in Myroniv and Kaniv districts.

The removal of erosion-endangered lands from production will have the most significant effect on landscape diversity of M28 testing grounds. The area of its ploughness on slopes over $3^{\circ}$ covers 0.54 sq.km, which is $3.5 \%$ from the total area of ploughness $15.42 \mathrm{sq} . \mathrm{km}$. The removal of these fields from production will promote the increase in landscape diversity by $11 \%$. Thus, even a slight correction in the land management structure via transferring erosion-critical arable

The values of Shannon diversity index while removing arable lands from production on slopes over $3^{\circ}$

\begin{tabular}{l|c|c|c}
\hline TAG & $\begin{array}{c}\text { Actual value } \\
\text { of Shannon } \\
\text { diversity } \\
\text { index }\end{array}$ & $\begin{array}{c}\text { Estimated value } \\
\text { f Shannon diversity } \\
\text { index while } \\
\text { removing lands } \\
\text { from production } \\
\text { on slopes over 3 }\end{array}$ & $\begin{array}{c}\text { Level } \\
\text { of change } \\
\text { in Shannon } \\
\text { diversity } \\
\text { index, \% }\end{array}$ \\
\hline K 9 & 0.41 & 0.41 & 0.29 \\
K 22 & 0.30 & 0.32 & $\mathbf{6 . 3 2}$ \\
K 27 & 0.65 & 0.66 & 1.08 \\
K 20 & 0.60 & 0.60 & 0 \\
K 7 & 0.89 & 0.89 & 0.38 \\
K 3 & 0.78 & 0.78 & 0 \\
M 2 & 0.79 & 0.83 & $\mathbf{5 . 8 3}$ \\
K 25 & 0.50 & 0.52 & $\mathbf{5 . 0 3}$ \\
K 24 & 0.79 & 0.80 & 1.27 \\
K 30 & 0.30 & 0.31 & 2.20 \\
K 12 & 0.69 & 0.76 & $\mathbf{9 . 9 4}$ \\
K 5 & 0.96 & 0.98 & 2.48 \\
M 4 & 0.70 & 0.74 & 4.65 \\
M 11 & 0.39 & 0.40 & 3.20 \\
M 12 & 0.40 & 0.41 & 4.30 \\
M 28 & 0.55 & 0.61 & $\mathbf{1 0 . 8 4}$ \\
M 15 & 0.56 & 0.56 & 1.05 \\
M 14 & 0.27 & 0.29 & 4.82 \\
M 26 & 0.40 & 0.41 & 2.44 \\
M 1 & 0.94 & 0.94 & 0 \\
\hline K & & \\
\hline
\end{tabular}

Note. The most significant increase in landscape diversity index is highlighted in semibold. lands to natural fields enhances anti-erosion resistance of agrolandscapes and their diversity considerably. It should be noted that satellite data about terrain parameters and structure of crop fields are rather successfully used in the modified RUSLE empirical model (Revised Universal Soil Loss Equation) [17], in the process of geomodelling of water-erosion processes within catch basins of rivers, which creates scientific and methodological foundations for the elaboration of a modern anti-erosion system in agrolandscapes on catch basin principles.

Therefore, the data of satellite imagery, use of landscape diversity indices, for instance, Shannon index, allows detecting zones with a low level of landscape diversity, determining their area and landscape elements, requiring the reduction in agrotechnical pressure on the environment via preservation of erosion-degraded and low performance lands, their transfer into natural fields, creation of water protection and recreation zones as well as conservation areas.

\section{CONCLUSIONS}

Satellite agroecological monitoring is an efficient instrument of determining the impact of climate warming on vegetation, processes of desertification and degradation of soils in agrolandscapes, their diversity and spatial distribution of erosion degradation of agricultural lands.

The suggested logical scheme of analyzing the manifestations of erosion degradation of catch basin agrolandscapes of small rivers on the grounds of using satellite data and geoinformation systems as well as landscape indices allows improving the integrated system of managing land, water, and biological resources, determining erosion-endangered territories of arable lands and forming optimal anti-erosion structure of agrolandscapes.

According to satellite data of NOAA for the last 35 years (1982-2017), the sum of effective temperatures for the vegetative period increased in Polissia zone (Chernihiv region) by $100{ }^{\circ} \mathrm{C}$, i.e. the average increase rate was $2.8{ }^{\circ} \mathrm{C}$ per year. In the Forest-Steppe (Poltava region) and Steppe (Zaporizhzhia region), the sum of effective temperatures for the period increased by $150^{\circ} \mathrm{C}$, or with the average increase rate of $4.3^{\circ}$ a year. Rather close correlation was established between the increase in the sum of effective temperatures for the period of 1982-2018 and NDVI index $(\mathrm{R}=0.64-0.77)$ within pilot territories of Polissia (Chernihiv region) and Forest-Steppe (Poltava region) which in general 
demonstrated positive impact of temperature increase in these regions on the vegetation. In the Steppe (Zaporizhzhia region) the correlation between the temperature increase and NDVI index dropped down to $\mathrm{R}=0.35$ which demonstrated a considerable decrease in positive effect from the temperature increase on the vegetation and, vice versa, the increased risk of droughts and desertification processes and the need to take measures on adapting agroecosystems of the Steppe to increasing risks of more severe droughts.

This article does not relate to any studies using humans and animals as investigation subjects.

Conflict of interests. The authors deny any conflict of interests.

Financing. This study did not receive any specific grant from the financing institutions in state, commercial or non-commercial sectors.

Супутниковий агроекологічний моніторинг в системі збалансованого природокористування

О. Г. Тараріко ${ }^{1}$, Т. В. Ільєнко ${ }^{1}$, Т. Л. Кучма ${ }^{1}$, I. О. Новаковська ${ }^{2}$

${ }^{1}$ Інститут агроекології і природокористування НААН, 12, вул. Метрологічна, Київ, Україна, 03143

${ }^{2}$ Національний авіаційний університет просп. Космонавта Комарова, 1, м. Київ, 03058 e-mail: tarariko@ukr.net

Супутникові дані $є$ важливим чинником інформаційного забезпечення збалансованого природокористування, оцінювання впливу господарської діяльності на екосистеми, визначення ризиків, пов'язаних з глобальними змінами клімату, процесами опустелювання, втратою ландшафтного і біотичного різноманіття. Мета. Обгрунтувати доцільність та довести ефективність використання супутникових даних в системі агроекологічного моніторингу щодо впливу змін клімату на рослинність, процесів ерозійної деградації грунтів та оцінювання ландшафтного різноманіття. Методи. Дослідження виконано на території України. Використано методологію SWOT та Gap-аналізу, матеріали космічного знімання NOAA, Sentinel, різного просторового розрізнення, методичне і нормативне забезпечення Інституту агроекології і природокористування Національної академії аграрних наук щодо супутникового моніторингу структури агроландшафтів, нормативів створення мережі тестових аграрних полігонів, переліку індикаторів стану рослинності, зокрема, «Дистанційне зондування Землі 3 космосу. Наземні дані щодо контролю стану посівів і продуктивності сільськогосподарських культур. Загальні вимоги: ДСТУ 7307:2013», «Дистанційне зондування Землі з космосу. Наземні обстеження посівів. Класифікатор об’єктів і функцій: СОУ 01.1-37-907:2011», «Ме- тодичні рекомендації зі створення мережі тестових аграрних полігонів в системі спостережень за посівами за матеріалами космічної інформації». Дослідження щодо впливу змін клімату на стан рослинності виконано на території трьох природно-кліматичних зон, які географічно представлено відповідно Чернігівською, Полтавською і Запорізькою областями. Визначення небезпеки прояву ерозійної деградації орних земель і ландшафтного різноманіття виконували на території двох адміністративних районів з високим рівнем розораності агроландшафтів, інтенсивного ведення аграрного виробництва та прояву ерозійної деградації земель. Результати. Встановлена недосконалість традиційної системи агроекологічного моніторингу. Доведена доцільність комплексного використання супутникових даних щодо потепління клімату в межах природно-кліматичних зон та його впливу на рослинність за вегетаційним індексом NDVI (Normalized Difference Vegetation Index), ерозійну деградацію грунтів та ландшафтне різноманіття. За супутниковими даними NOAA (National Oceanic and Atmospheric Administration) виконано кореляційний аналіз зв'язку між динамікою суми ефективних температур та суми значень NDVI за вегетаційний період. Встановлено позитивний вплив потепління клі-мату на стан рослинності за показником NDVI в зоні Полісся i Лісостепу. Коефіцієнт кореляції відповідно склав $\mathrm{R}=$ $=0,64$ та $\mathrm{R}=0,77$. В зоні Степу коефіцієнт кореляції зменшується до $\mathrm{R}=0,35$, що свідчить про зростання ризику прояву посушливих явищ. Висновки. За супутниковими даними Sentinel-1 визначено критичні зони ерозійної деградації орних земель, які потребують консервації та включення їх до складу природних угідь, що позитивно впливає на оптимізацію різноманіття агроландшафтів.

Ключові слова: супутниковий агроекологічний моніторинг, тестовий аграрний полігон, ландшафтне різноманіття, потепління клімату, посушливі явища, ерозійна деградація грунту, супутникові дані, збалансоване природокористування, вегетаційні та ландшафтні індекси.

\section{Спутниковый агроэкологический мониторинг} в системе устойчивого природопользования

$$
\begin{aligned}
& \text { О. Г. Тарарико }{ }^{1} \text {, Т. В. Ильенко }{ }^{1} \text {, } \\
& \text { Т. Л. Кучма }{ }^{1} \text {, И. О. Новаковская }{ }^{2}
\end{aligned}
$$

${ }^{1}$ Институт агроэкологии и природопользования НААН, 12, ул. Метрологическая, Киев, Украина, 03143

${ }^{2}$ Национальний авиационный университет

$$
\text { e-mail: tarariko@ukr.net }
$$

Спутниковая информация является важным фактором информационного обеспечения устойчивого природопользования, оценки воздействия хозяйственной деятельности на экосистемы, определения рисков для сельского хозяйства, связанных с глобальными изменени- 
ями климата, процессами опустынивания и деградации земель, а также ландшафтного разнообразия. Цель. Обосновать целесообразность и показать эффективность использования спутниковых данных в системе агроэкологического мониторинга по вопросам изменений климата и его влияния на растительность, процессы эрозионной деградации почв и оценки ландшафтного разнообразия. Методы. Исследование выполнено на территории Украины. Использована методология SWOT и Gap-анализа, материалы спутниковых снимков NOAA и Sentinel-1, методическое и нормативное обеспечение Института агроэкологии и природопользования Национальной академии аграрных наук по методическому обеспечению спутникового мониторинга структуры агроландшафтов, нормативов создания сети тестовых аграрных полигонов, перечня индикаторов состояния растительности, в частности «Дистанционное зондирование Земли из космоса. Наземные данные по контролю состояния посевов и продуктивности сельскохозяйственных культур. Общие требования: ДСТУ 7307: 2013», Дистанционное зондирование Земли из космоса. Наземные обследования посевов. Классификатор объектов и функций: СОУ 01.1-37-907:2011. Исследования о влиянии изменений климата на состояние растительности выполнено на территории природно-климатических зон Полесья, Лесостепи и Степи, которые географически представлены Черниговской, Полтавской и Запорожской областями. Определение опасности проявления эрозионной деградации пахотных земель и ландшафтного разнообразия выполнялось на территории двух административных районов - Мироновского района Киевской области и Каневского района Черкасской области с высоким уровнем распаханности агроландшафтов, интенсивного ведения аграрного производства, высоким риском проявления эрозионной деградации земель. Результаты. В результате SWOT и Gap-анализа реализации положений природоохранных Конвенций ООН по изменению климата, опустыниванию и биологическому разнообразию в сфере сельского хозяйства установлено, что общим слабым местом для выполнения является несовершенство информационного обеспечения. Доказана целесообразность комплексного использования спутниковых данных для мониторинга потепления климата в пределах природноклиматических зон и его влияния на растительность по показателю NDVI, эрозионную деградацию почв и ландшафтное разнообразие. По спутниковым данным NOAA выполнен корреляционный анализ связи между динамикой суммы эффективных температур и суммы NDVI за вегетационный период. Установлено положительное влияние потепления климата на состояние растительности по показателю NDVI в зоне Полесья и Лесостепи. Коэффициент корреляции соответственно составлял $\mathrm{R}=0,64$ и $\mathrm{R}=0,77$. В зоне Степи коэффициент корреляции уменьшается до $\mathrm{R}=0,35$, что свидетельствует о росте риска проявления засушливых явлений. Выводы. По спутниковым данным Sentinel-1 определены критические зоны эрозионной деградации пахотных земель, требующих консервации, включение их в природные угодья, что оптимизирует разнообразие агроландшафтов.

Ключевые слова: спутниковый агроэкологический мониторинг, тестовый аграрный полигон, ландшафтное разнообразие, потепление климата, засушливые явления, эрозионная деградация почвы, спутниковые данные, устойчивое природопользование, вегетационные и ландшафтные индексы.

\section{REFERENCES}

1. The official site of the National Academy for Public Administration under the President of Ukraine (2014), "Passport of the UNDP/GEF Project "Integrating Rio Convention Provisions into Ukraine's National Policy Framework", available at: http://academy.gov.ua/pages/ dop/19/files/6755dbde-4d54-4c57-a454-4ff8050f65bc. pdf.

2. Tarariko OH, Demydov OA, Andrushchenko AV, Kocherha MM, Syrotenko OV, Mykytenko MT, Ilienko TV, Kuchma TL, Mynkevych NA, Mudryk SH, Frolova OM, Kapustin YeI, Parshyna OI, Sablina VI. Methodological recommendations on agroecological evaluation of the structure of agrolandscapes and systems of land use using the data of remote sensing of the globe with high spatial resolution. K., 2012:33 c. doi: 10.5281/ zenodo.1401212. [in Ukrainian]

3. Tarariko $O H$, Syrotenko $O V$, Ilienko $T V$, Kuchma TL, Mynkevych NA, Mudryk SH. Methodological recommendations on determining and identifying water erosion of soils in agrolandscapes using spatial imagery of high spatial resolution. K., 2013:31c. doi: 10.5281/ zenodo.1401255. [in Ukrainian]

4. Brodsky L, Bushuev EI, Voloshin VI, Kozlova AA, Parshina OI, Popov MA, Sablina VI, Sakhatskyi AI, Syrotenko AV, Soukup T, Stankevich SA, Tarariko AG. The INTAS project for the elaboration of automated technology of land cover classification: the scientific problems, main results and prospects. Kosmichna nauka i tekhnologiya. 2009, 15 ;(2):036-048 https://doi. org/10.15407/knit2009.02.036

5. AVHRR Level 1b Product Guide. EUM/OPS-EPS/ MAN/04/0029, Issue: v3A., Germany, 2011:98 p.

6. McGarigal K, Marks BJ. FRAGSTATS: spatial pattern analysis program for quantifying landscape structure. Gen. Tech. Rep. PNW-GTR-351. Portland, OR: U.S. Department of Agriculture, Forest Service, Pacific Northwest Research Station. 1995:122 p. doi: https://doi. org/10.2737/PNW-GTR-351.

7. Tarariko $\mathrm{OH}$. SWOT-analysis and GAP-analysis of 


\section{SATELLITE AGROECOLOGICAL MONITORING WITHIN THE SYSTEM}

policies, programs, plans and legislative acts in the field of agriculture and preparing recommendations on their improvement in accordance to the Rio Conventions. Kherson: individual entrepreneur D.S. Hrin, 2016:104 p. http://www.ua.undp.org/content/dam/ukraine/docs/EE/ Rio/Rio-2_Silske-gospodarstvo.pdf [in Ukrainian]

8. Martazinova VF, Tymofeyev VE, Ivanova EK, Chay$k a D Y$. The present-day climate of eastern Europe as viewed in the context of atmospheric circulation change. Bulletin of Geography - physical geography series. 2009, no. 1:7-18, doi: 10.2478/bgeo-2009-0001.

9. The Economics of Ecosystems and Biodiversity (TEEB) in National and International Policy Making. Edited by Patrick ten Brink. Earthscan, London and Washington. 2011:429 p.

10. Delworth TL, Broccoli AJ, Rosati A, Stouffer RJ, Balaji V, Beesley JA, Cooke WF, Dixon KW, DunneJ, Dunne KA, Durachta JW, Findell KL, Ginoux P, Gnanadesikan A, Gordon CT, Griffies SM, Gudgel R, Harrison MJ, Held IM, Hemler RS, Horowitz LW, Klein SA, Knutson TR, Kushner PJ, Langenhorst AR, Lee H-C, Lin S-J, Lu $J$, Malyshev SL, Milly PCD, Ramaswamy V, Russell J, Schwarzkopf MD, Shevliakova E, Sirutis JJ, Spelman MJ, Stern WF, Winton M, Wittenberg AT, Wyman $B$, Zeng $F$, Zhang $R$. GFDL's CM2 Global Coupled Climate Models. Part I: Formulation and Simulation Characteristics. J. Climate. 2006;19:643-74. https://doi. org/10.1175/JCLI3629.1.
11. Belkin JM. Rapid Warming of Large Marine Ecosystems. Prog. in Oceanogr. 2009, vol. 81:207-13. doi: 10.1016/j. pocean.2009.04.011.

12. Kogan FN. Application of vegetation index and brightness temperature for drought detection. Adv. Space Res., 1995,15(11): 91-100. https://doi.org/10.1016/02731177(95)00079-T.

13. IPCC, 2014: Climate Change 2014: Synthesis Report. Contribution of Working Groups I, II and III to the Fifth Assessment Report of the Intergovernmental Panel on Climate Change [Core Writing Team, R.K. Pachauri and L.A. Meyer (eds.)]. IPCC, Geneva, Switzerland, 151 pp. 14. Novakovska I, Bulgakov V, Ivanov S, Dukulis I. Formation of sustainable land-use systems in erosion dangerous landscapes. Engineering for rural development, 2018;17:378-86. https://doi: 10.22616/ERDev2018.17. N489.

15. Petrychenko VF, Tarariko OH, Syrotenko OV. Space Technologies in Agri-Environmental Monitoring System. Agric. sci. pract., 2014;1(1):3-12. https://doi.org/ 10.15407/agrisp1.01.003.

16. Kuchma T, Tarariko O, Syrotenko O. Landscape diversity indexes application for agricultural land use optimization. Procedia Technology, 2013; 8:566-9.

17. Benavidez R, Jackson B, Maxwell D, Norton K. A review of the (Revised) Universal Soil Loss Equation ((R) USLE): with a view to increasing its global applicability and improving soil loss estimates, Hydrol. Earth Syst. Sci., 2018,22(11):6059-86. https://doi.org/10.5194/hess- 